\title{
Surface Microstructure of Monocrystalline Silicon Anisotropically Etched with Sodium Carbonate and Sodium Bicarbonate Solutions
}

\author{
Junjun $\mathrm{Ma}^{1, \mathrm{a}}{ }^{*}$ and Shiqing Man ${ }^{2, \mathrm{~b}}$ \\ ${ }^{1,2}$ School of Physics and Electronic Information Technology, Yunnan Normal University, Kunming, \\ Yunnan, China \\ a2754127618@qq.com, bman_shiqing@yahoo.com
}

Keywords: Microstructure; Monocrystalline silicon; Anisotropic etching; Uniformity

\begin{abstract}
The surface microstructure fabrication of monocrystalline silicon by anisotropic etching with sodium carbonate and sodium bicarbonate solutions have been studied in this paper. The microstructure fabrication process has been evaluated in terms of the surface morphology size, etching condition and uniformity. The experiments show that with the solution temperature changing, the average size of microstructure varies from $0.62 \mu \mathrm{m}$ to $1.42 \mu \mathrm{m}$. Similarly, with the etching time increasing from $10 \mathrm{~min}$ to $40 \mathrm{~min}$, the average size of microstructure varies from $0.62 \mu \mathrm{m}$ to $1.12 \mu \mathrm{m}$. On the basis of our experiments, it is concluded that the optimized condition is 24 wt $\% \mathrm{Na}_{2} \mathrm{CO}_{3}, 4$ wt $\% \mathrm{NaHCO}_{3}, 90{ }^{\circ} \mathrm{C}$ and $30 \mathrm{~min}$. Under optimum conditions, the silicon wafers surface exhibit a lower average size of $0.62 \mu \mathrm{m}$ and the microstructures are uniform and continuous. It is hoped that it may lead to an increase in the microfabrication of manufacturing industry. Therefore, this promising technique provides an alternative way for the microstructure fabrication of monocrystalline silicon in the industrial production.
\end{abstract}

\section{Introduction}

In the past few years, the nanotechnology have attracted interest from the manufacturing industry owing to the good properties of crystalline silicon. The silicon surfaces functionality increasing is of high importance for various applications [1]. In all of these, one particular approach for implementing multifunctionality is the formation of surface microstructure. These surface microstructures have high conversion efficiencies, high opencircuit voltages and low temperature coefficients [2]. At present, nanoelectronic devices and nanomachines could soon be manufactured by manipulating atoms and molecules. Microfabrication is essential for the development of these nanotechnologies but remains challenging. There are several methods for preparation of microstructure, the chemical etching with anisotropic texturing solutions being one of the simplest and effective. In order to get smaller and more uniform microstructure in wet etching, it is important to control the parameters.

As for microstructure fabrication of monocrystalline silicon, alkaline solution such as sodium hydroxide $(\mathrm{NaOH})$ or potassium hydroxide $(\mathrm{KOH})$ with isopropyl alcohol (IPA) is generally used in order to achieve good uniformity of pyramidal structures on the silicon surface [3]. The theory is

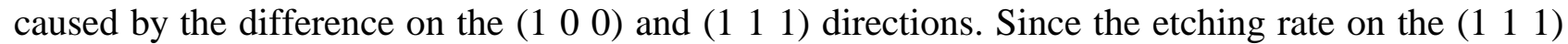
direction is much slower than $\left(\begin{array}{lll}1 & 0 & 0\end{array}\right)$ direction, so the strong dependence of etch rates on crystal orientation leads to pyramid formation on $\left(\begin{array}{lll}1 & 0 & 0\end{array}\right)$ silicon surfaces [4]. However, IPA is expensive and volatile especially in a heated etching bath [5]. To eliminate these disadvantages of IPA, some researchers used other salt solutions, like sodium carbonate $\left(\mathrm{Na}_{2} \mathrm{CO}_{3}\right)$ [6], potassium carbonate $\left(\mathrm{K}_{2} \mathrm{CO}_{3}\right)$ [7] and sodium phosphate $\left(\mathrm{Na}_{3} \mathrm{PO}_{4}\right)$ [8]. Particularly, $\mathrm{Na}_{2} \mathrm{CO}_{3}$ has a lower cost than the other referred compounds, and is not as unhealthy to manipulate as the other compounds referred. Thus, $\mathrm{Na}_{2} \mathrm{CO}_{3}$ seems to be the best etchant for the microstructure fabrication of monocrystalline silicon. In this paper, a series of comparative experiments on texturization using $\mathrm{Na}_{2} \mathrm{CO}_{3}$ and $\mathrm{NaHCO}_{3}$ solutions have been carried out and the results of microstructure fabrication have also been presented. 


\section{Experiments}

Experimental Principle. Sodium carbonate and sodium bicarbonate can hydrolyze in water. The equations are as follows:

$$
\begin{aligned}
& \mathrm{CO}_{3}{ }^{2-}+\mathrm{H}_{2} \mathrm{O} \rightleftharpoons \mathrm{HCO}_{3}^{-}+\mathrm{OH}^{-} \\
& \mathrm{HCO}_{3}{ }^{-}+\mathrm{H}_{2} \mathrm{O} \rightleftharpoons \mathrm{H}_{2} \mathrm{CO}_{3}+\mathrm{OH}^{-}
\end{aligned}
$$

Therefore, in the $\mathrm{Na}_{2} \mathrm{CO}_{3}$ and $\mathrm{NaHCO}_{3}$ solutions, the $\mathrm{OH}^{-}$is generated which forms small pyramids and $\mathrm{CO}_{3}{ }^{2-}$ or its compounds help for forming big pyramids. Moreover, the $\mathrm{HCO}_{3}{ }^{-}$plays the role of a surface active agent which can decrease the active energy of the texturing reaction and then makes texturization of silicon surface more effective [9].

Experimental Process. The experiments were performed with P-type $\langle 100\rangle$ oriented monocrystalline silicon. All the silicon samples with the size of $20 \mathrm{~mm} \times 20 \mathrm{~mm}$ were cut from adjacent wafers [10]. Before etching, wafers were cleaned by the following procedures. The first step was to degrease the samples by cleaning the wafers in ethanol during five minutes. The second step was to remove damage on the surface caused by sawing [11]. This step was carried out in diluted hydrofluoric acid (4 wt $\%$ ) for $30 \mathrm{~s}$ and rinsed in deionised water. The cleaned wafers were took place in a specially designed of the sealing device inside the mixed solution for a desired time. Then these samples were etching in different temperature: $80^{\circ} \mathrm{C}, 84^{\circ} \mathrm{C}, 88^{\circ} \mathrm{C}, 92^{\circ} \mathrm{C}$. Next, the wafers were kept in solution for different time: $10 \mathrm{~min}, 20 \mathrm{~min}, 30 \mathrm{~min}, 40 \mathrm{~min}$. After the etching process, the samples were washed into absolute ethanol solution and deionized water again, and then they were dried oven for tests. The surface morphology was measured by a scanning electron microscopy (SEM) [12].

\section{Results and Discussion}

Microstructure Evolution at Different Solution Temperature. According to our previous work, we know the solution temperature and etching time have a large effect on texturing of monocrystalline silicon. In order to elucidate the influence of the solution temperature on the surface microstructure properties, the $\mathrm{Na}_{2} \mathrm{CO}_{3}$ and $\mathrm{NaHCO}_{3}$ concentration were kept at $24 \mathrm{wt} \%$ and $4 \mathrm{wt} \%$, the etching time was remain unchanged for $30 \mathrm{~min}$, while the solution temperature was varied between $82{ }^{\circ} \mathrm{C}$ and $94{ }^{\circ} \mathrm{C}$. Table 1 summarizes the size, etching condition and uniformity of microstructure.

Table 1 Comparison of the microstructure size, etching condition and uniformity at different solution temperature.

\begin{tabular}{cccccc}
\hline $\begin{array}{c}\text { Temperature } \\
{\left[{ }^{\circ} \mathrm{C}\right]}\end{array}$ & $\begin{array}{c}\text { Maximum Size } \\
{[\mu \mathrm{m}]}\end{array}$ & $\begin{array}{c}\text { Minimum Size } \\
{[\mu \mathrm{m}]}\end{array}$ & $\begin{array}{c}\text { Average Size } \\
{[\mu \mathrm{m}]}\end{array}$ & Fully Etched & Uniformity \\
\hline 82 & 2.36 & 0.73 & 1.42 & No & Low \\
86 & 1.55 & 0.66 & 1.08 & Yes & Regular \\
90 & 0.77 & 0.34 & 0.62 & Yes & High \\
94 & 0.78 & 0.35 & 0.64 & Yes & High \\
\hline
\end{tabular}

From the table, it can be seen that the size of the biggest microstructure is $2.36 \mu \mathrm{m}$ and the smallest microstructure is $0.34 \mu \mathrm{m}$, average size varies from $0.62 \mu \mathrm{m}$ to $1.42 \mu \mathrm{m}$. In the case of solution temperature, the average size becomes smaller with increasing temperature, but as the solution temperature reaches $90{ }^{\circ} \mathrm{C}$, the average size changes little. So $90{ }^{\circ} \mathrm{C}$ can be considered as the ideal temperature. In this case, the minimum average size is $0.62 \mu \mathrm{m}$. Besides, the surfaces were completely etched and the uniformity is high.

The SEM images of microstructure fabrication process with different solution temperature are schematically shown in Fig. 1. The pictures show that the etching produced pits which are random on the silicon surfaces. A number of pits were formed on surfaces of samples, which were obviously when the solution temperature is $90{ }^{\circ} \mathrm{C}$ and the shapes of microstructure were kept well. We also found that it is difficult to get a smaller and uniform microstructure when the solution temperature below $86{ }^{\circ} \mathrm{C}$ and $90{ }^{\circ} \mathrm{C}$ can obtain an excellent microstructure. 



Figure 1. SEM images of monocrystalline silicon wafers surface microstructure textured at different solution temperature: $\mathrm{a}_{1}\left(82^{\circ} \mathrm{C}\right), \mathrm{a}_{2}\left(86^{\circ} \mathrm{C}\right), \mathrm{a}_{3}\left(90^{\circ} \mathrm{C}\right), \mathrm{a}_{4}\left(94^{\circ} \mathrm{C}\right)$.

Fig. 2 shows the distribution of microstructure sizes under different temperature. It can be clearly seen that the uniformity has been improved by increasing the solution temperature. We can get more uniform and continuous microstructure when the temperature reaches $90^{\circ} \mathrm{C}$. In this ideal temperature, most diameter sizes of microstructure are between $0.5 \mu \mathrm{m}$ and $0.7 \mu \mathrm{m}$, which account for $89 \%$. All these data indicate that the solution temperature has a large effect on the microstructure fabrication process of monocrystalline silicon.
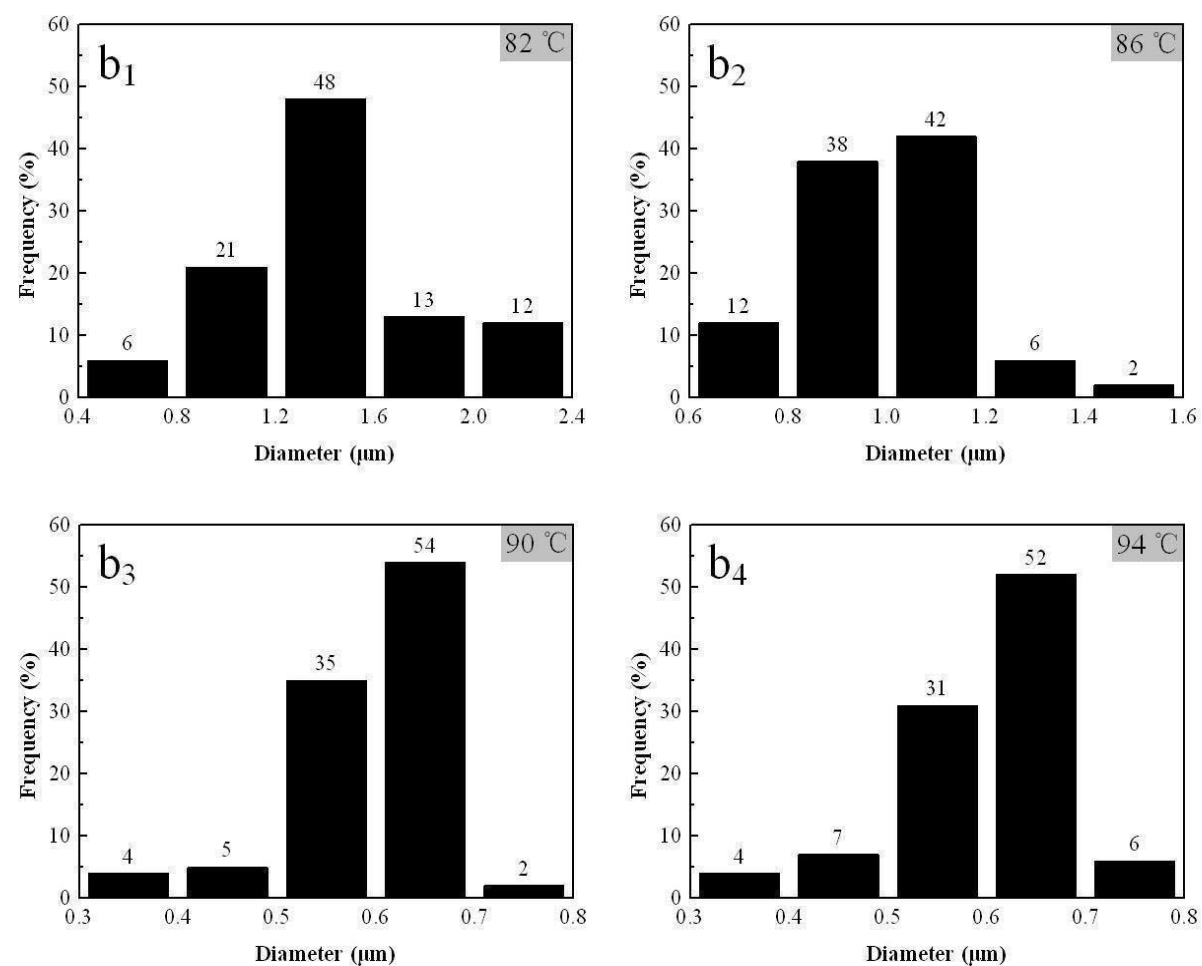

Figure 2. Distribution of microstructure sizes at different solution temperature: $\mathrm{b}_{1}\left(82^{\circ} \mathrm{C}\right), \mathrm{b}_{2}\left(86{ }^{\circ} \mathrm{C}\right)$, $\mathrm{b}_{3}\left(90^{\circ} \mathrm{C}\right), \mathrm{b}_{4}\left(94^{\circ} \mathrm{C}\right)$. 
Microstructure Evolution for Different Etching Time. Next, we studied the influence of the etching time on the microstructure properties. In order to achieve good uniformity microstructure of monocrystalline silicon, the $\mathrm{Na}_{2} \mathrm{CO}_{3}$ concentration was fixed at $24 \mathrm{wt} \%$, the $\mathrm{NaHCO}_{3}$ concentration was fixed at $4 \mathrm{wt} \%$ and the solution temperature was also maintained at $90{ }^{\circ} \mathrm{C}$. We changed the etching time from $10 \mathrm{~min}$ to $40 \mathrm{~min}$ and conducted four groups of experiments. As a result of experiments, all of the size, etching condition and uniformity of microstructure are listed in Table 2.

Table 2 Comparison of the microstructure size, etching condition and uniformity for different etching time.

\begin{tabular}{cccccc}
\hline $\begin{array}{c}\text { Time } \\
{[\mathrm{min}]}\end{array}$ & $\begin{array}{c}\text { Maximum Size } \\
{[\mu \mathrm{m}]}\end{array}$ & $\begin{array}{c}\text { Minimum Size } \\
{[\mu \mathrm{m}]}\end{array}$ & $\begin{array}{c}\text { Average Size } \\
{[\mu \mathrm{m}]}\end{array}$ & Fully Etched & Uniformity \\
\hline 10 & 2.16 & 0.63 & 1.12 & No & Low \\
20 & 0.95 & 0.52 & 0.64 & Yes & Regular \\
30 & 0.79 & 0.34 & 0.62 & Yes & High \\
40 & 1.52 & 0.67 & 0.88 & Yes & Regular \\
\hline
\end{tabular}

From the table, it is also noticed that the biggest microstructure is $2.16 \mu \mathrm{m}$ and the smallest microstructure is $0.34 \mu \mathrm{m}$, average size varies from $0.62 \mu \mathrm{m}$ to $1.12 \mu \mathrm{m}$. As the table shows, the microstructure gets better as the etching time increases. However, when the etching time was more than $30 \mathrm{~min}$, the size of microstructure began to largen gradually. When the reaction lasted for $30 \mathrm{~min}$, the minimum average size is $0.62 \mu \mathrm{m}$. According to these data, it is deduced that $30 \mathrm{~min}$ was the optimum etching time.

Fig. 3 is the SEM images of microstructure for samples with different etching time. On the basis of presented diagram, it can be stated that, in the range of examined etching time, thirty minutes was estimated as the optimum value, because for shorter time, the surfaces showed bright regions without etching. By contrast, when the reaction time was prolonged above $30 \mathrm{~min}$, no improvement of the microstructure surfaces was noticed. When etched thirty minutes, good surface size and etching condition are obtained. Moreover, the microstructures are uniform.
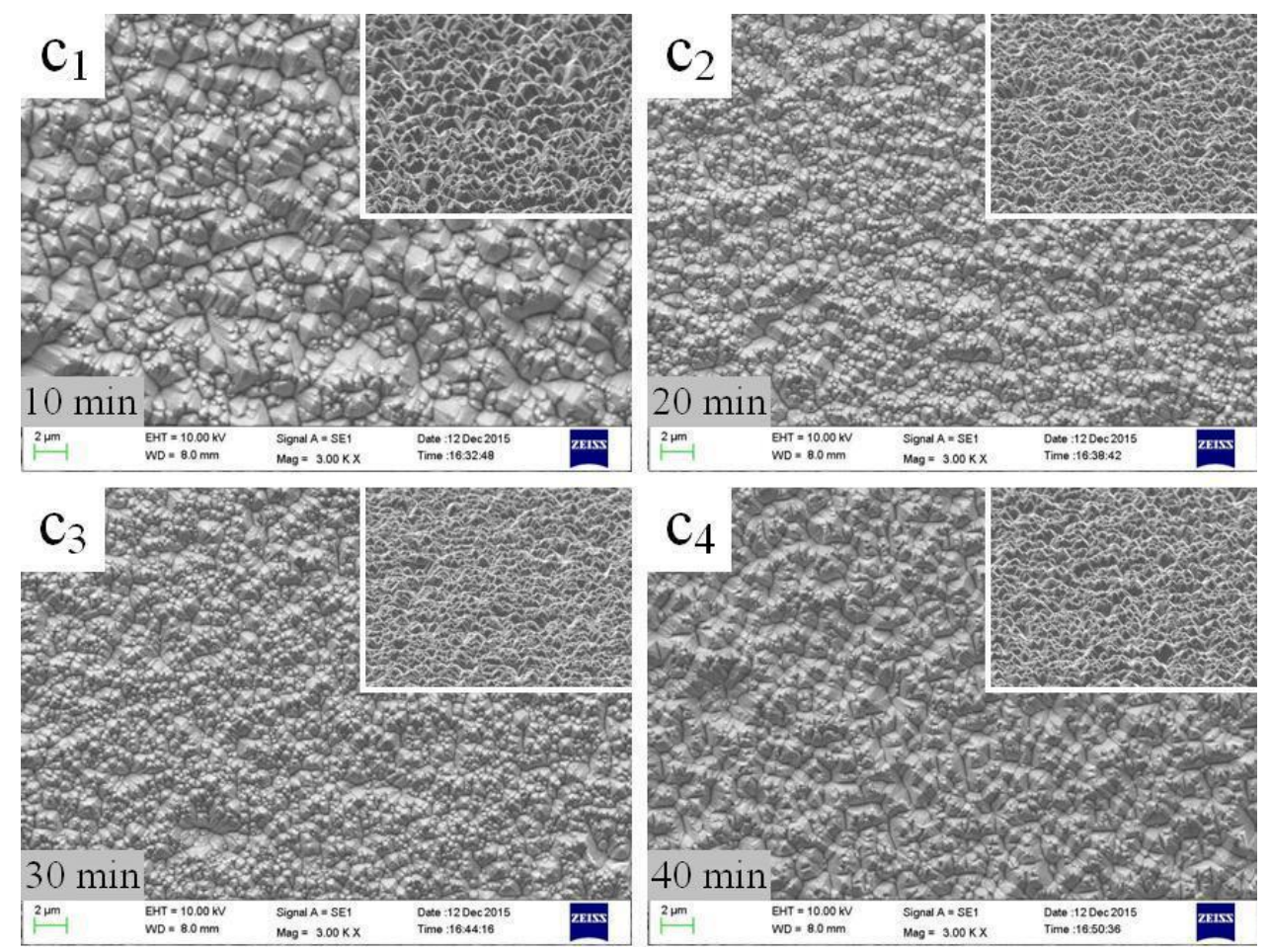

Figure 3. SEM images of monocrystalline silicon wafers surface microstructure textured for different etching time: $\mathrm{c}_{1}(10 \mathrm{~min}), \mathrm{c}_{2}(20 \mathrm{~min}), \mathrm{c}_{3}(30 \mathrm{~min}), \mathrm{c}_{4}(40 \mathrm{~min})$. 
The distribution of microstructure sizes with different etching time is schematically shown in Fig. 4. From the image study, it could be found that the uniformity of microstructure got improved with increasing etching time. As previously described, an optimum treatment time of 30 min was determined. Under this condition, we observed that the sizes of most microstructure vary from $0.5 \mu \mathrm{m}$ to $0.7 \mu \mathrm{m}$ and the percentage of sizes on the whole area account for $87 \%$. It indicates that the etching time is also an important factor for the fabrication of microstructure.
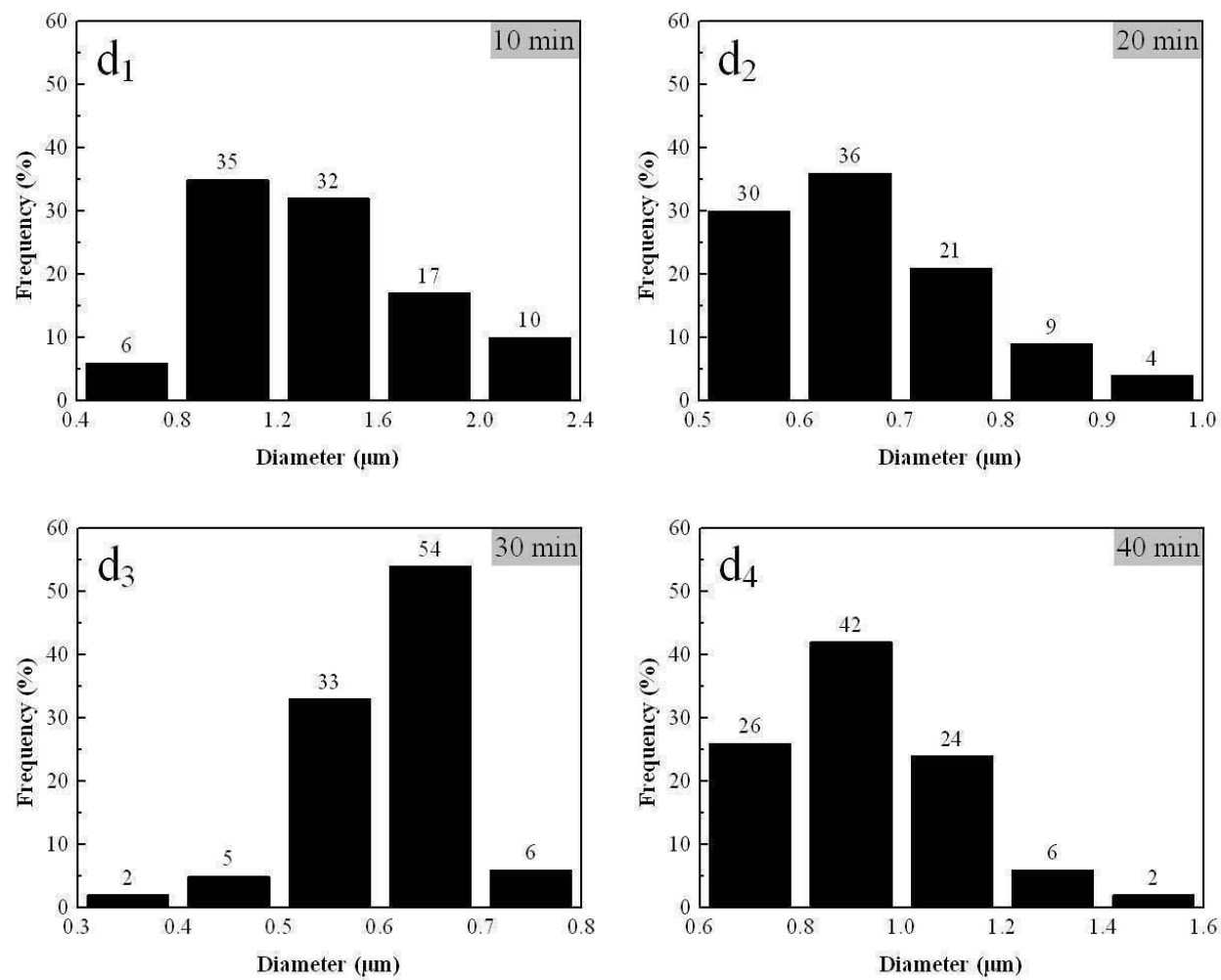

Figure 4. Distribution of microstructure sizes for different etching time: $d_{1}(10 \mathrm{~min}), \mathrm{d}_{2}$ (20 min),

$$
\mathrm{d}_{3}(30 \mathrm{~min}), \mathrm{d}_{4}(40 \mathrm{~min}) \text {. }
$$

\section{Conclusions}

In this paper, the process of microstructure fabrication with sodium carbonate and sodium bicarbonate solutions have been studied. In order to achieve good uniformity microstructure, we changed the solution temperature from $82{ }^{\circ} \mathrm{C}$ to $94{ }^{\circ} \mathrm{C}$ and varied the etching time from $10 \mathrm{~min}$ to $40 \mathrm{~min}$. Based on the experiments, it is found that the solution temperature and the etching time determine the surface microstructure of monocrystalline silicon. Meanwhile, the size, etching condition and uniformity of microstructure have been also studied. All the experiments have indicated that there is remarkably different microstructure with different solution temperature and etching time. Besides, the optimized condition is $24 \mathrm{wt} \% \mathrm{Na}_{2} \mathrm{CO}_{3}, 4 \mathrm{wt} \% \mathrm{NaHCO}_{3}, 90{ }^{\circ} \mathrm{C}$ and $30 \mathrm{~min}$. Under these conditions, uniform microstructure were obtained and the average size of diameter is $0.62 \mu \mathrm{m}$. Due to its nonhazardous, lower costs and better process control comparable to the ones obtained in IPA-based solutions, so this etching method is suitable to produce in a large scale for the microstructure fabrication of monocrystalline silicon.

\section{Acknowledgements}

This work was supported by the National Natural Science Foundation of China (NSFC) (Grant No. 21171072 and Grant No. 21361028). 


\section{References}

[1] H. Han, Z. Huang and W. Lee, Metal-assisted chemical etching of silicon and nanotechnology applications, Nano Today, vol. 9, no. 3, 2014, pp. 271-304.

[2] M. J. Hohann, G. Petzow, M. J. Hohann and etal, Tailored microstructures of silicon nitride ceramics, Cheminform, vol. 25, no. 9, 2010, pp. 1807-1814.

[3] E. Vazsonyi, C. Ducsho and A. Pekker, Characterization of the anisotropic etching of silicon in two-component alkaline solution, Journal of Micromechanics and Microengineering, vol. 17, no. 9, 2007, pp. 1916-1922.

[4] D. Resnik, D. Vrtacnik, U. Aljancic and etal, The role of triton surfactant in anisotropic etching of $\left\{\begin{array}{lll}1 & 1 & 0\end{array}\right\}$ reflective planes on $\left\{\begin{array}{lll}1 & 0 & 0\end{array}\right\}$ silicon, Journal of Micromechanics and Microengineering, vol. 15 , no. 6,2005 , pp. $1174-1183$.

[5] G. S. Chung and T. S. Kim, The effect of pyrazine on TMAH:IPA single-crystal silicon anisotropic etching properties, Transactions on Electrical and Electronic Materials, vol. 2, no. 2, 2001, pp. 21-25.

[6] Y. Nishimoto and K. Namba, Investigation of texturization for crystalline silicon solar cells with sodium carbonate solutions, Solar Energy Materials and Solar Cells, vol. 61, no. 4, 2000, pp. 393-402.

[7] R. Chaoui, M. Lachab, F. Chiheub and etal, Proceedings of the 14th European Photovoltaic Solar Energy Conference, Barcelona, 1997, pp. 812-814.

[8] W. Sparber, O. Schultz, D. Biro and etal, Proceedings of 3rd World Conference on Photovoltaic Energy Conversion, Osaka, 2003, pp. 122-125.

[9] R. Barrio, N. Gonzalez, J. Carabe and etal, Texturization of silicon wafers with $\mathrm{Na}_{2} \mathrm{CO}_{3}$ and $\mathrm{Na}_{2} \mathrm{CO}_{3} / \mathrm{NaHCO}_{3}$ solutions for heterojunction solar-cell applications, Materials Science in Semiconductor Processing, vol. 16, no. 1, 2013, pp. 1-9.

[10] F. Z. Fang, H. Wu and Y. C. Liu, Modelling and experimental investigation on nanometric cutting of monocrystalline silicon, International Journal of Machine Tools and Manufacture, vol. 45, no. 15, 2005, pp. 1681-1686.

[11] P. A. Deymier, J. O. Vasseur, A. Khelif and etal, Second-order sound field during megasonic cleaning of patterned silicon wafers: application to ridges and trenches, Journal of Applied Physics, vol. 90, no. 8, 2001, pp. 4211-4218.

[12] T. Verduin, P. Kruit and C. W. Hagen, Determination of line edge roughness in low dose top-down scanning electron microscopy images, Metrology Inspection and Process Control for Microlithography XXVIII, vol. 9050, no. 15, 2014, pp. 1654-1658. 